\title{
Physicochemical properties
}

\begin{abstract}
Background: Dendrobium officinale as a precious traditional Chinese herb is widely used in medicines and health supplements. Thus the extraction, purification and biological activities of polysaccharides from the stem of Dendrobium officinale have significant meaning on theory and application value.

Methods: The crude Dendrobium officinale polysaccharide (DOP) was obtained by hot water extraction- ethanol precipitation method, and four new polysaccharide fractions (DOP-40, DOP-50, DOP-60, and DOP-70) were further obtained from the crude DOP by fractional precipitation with ethanol method, then four fractions were further purified by Toyopearl-H65F gel resin. The molecular weight and monosaccharide composition of four purified fractions were determined by high performance anion exchange chromatography and high performance liquid chromatography. The antioxidant activities of them were evaluated by the reducing power assay, and the superoxide anion, 2,2-diphenyl-1-picrylhydrazyl (DPPH), and hydroxyl free radicals scavenging assays, respectively. Finally, the anticancer activities of them were investigated via the MTT assay and the western blot analysis using HepG2 cells.

Results: Among these four purified fractions were mainly composed of D-mannose and D-glucose with different molar ratios, and their average molecular weights were 999, 657, 243 and $50.3 \mathrm{kDa}$, respectively. What's more, DOP70 always exhibited the strongest antioxidant and anticancer activities, while DOP-40 and DOP-60 showed very close antioxidant and anticancer activities which were better than that of DOP-50. The western blotting analysis also showed that DOP-40, DOP-60, and DOP-70 induced apoptosis in HepG2 human liver cancer cells through the Bcl-2 and Bax-dependent pathway.

Conclusions: Fractional precipitation with ethanol could successfully apply to extract four new polysaccharide fractions from Dendrobium officinale stems, and the polysaccharide fractions possessed efficient antioxidant and anticancer activities, especially DOP-70.
\end{abstract}

Keywords: Dendrobium officinale, Polysaccharide fractions, Fractional precipitation, Antioxidant activity, HepG2 cells

\footnotetext{
*Correspondence: weigang021@outlook.com

${ }^{1}$ School of Pharmaceutical Science, Guangzhou University of Chinese

Medicine, Guangzhou 510006, China

Full list of author information is available at the end of the article
} 


\section{Background}

Dendrobium officinale, a perennial epiphytic herb in the Orchidaceae family, is the most precious species in Dendrobium genus found in Zhejiang, Anhui, Yunnan and Guangxi provinces of China [1,2]. Its stem has been traditionally consumed as both food and medicine recorded in "Pharmacopoeia of the People's Republic of China", and it has been proved to possess enhancing immunity, anti-inflammatory, antioxidant and anticancer activities [3-5]. In recent years, increasing evidence proved its potentially significant functions and its slow growth rate, which resulted in a sharp rise in its price and more studies on its chemical constituents and biological activities $[6,7]$.

Recently, extensive studies have been demonstrated that polysaccharides from Dendrobium officinale stems possessed could protect RAW 264.7 cells against oxidative injury [8], inhibit TNF-a-induced apoptosis in A-253 cell line [9], and enhance intestinal mucosal immune activity [10]. To date, fractional precipitation with ethanol has already become a rapid, feasible and reproducible way to extract initial purify of aqueous extracts [11]. In addition, different concentrations of ethanol have been reported to generate corresponding protein content, molecular weight, monosaccharide composition and bioactivity of the products [12]. However, the physicochemical properties and functions of polysaccharide fractions from Dendrobium officinale stems extracted by ethanol fractional precipitation method still remained unknown. In this study, four new polysaccharide fractions were obtained via fractional precipitation, and their bioactivities were further evaluated with the purpose of providing novel natural antioxidant and anticancer compounds from Dendrobium officinale stems.

\section{Experimental}

Plant material

Dendrobium officinale were collected from the Zhejiang Province in China (Fig. 1), as we described previously [8]. The voucher specimens were preserved in the School of Pharmaceutical Science. The stems of Dendrobium officinale were dried up at $60{ }^{\circ} \mathrm{C}$ and ground into fine powder for the subsequent studies.

\section{Cell culture}

The human liver cancer HepG2 cells were obtained from Shanghai Cell Bank (Shanghai, China). HepG2 cells cultured in DMEM medium (10\% (v/v) FBS, $100 \mathrm{mg} / \mathrm{ml}$ streptomycin and $100 \mathrm{U} / \mathrm{ml}$ penicillin) and incubated at $37^{\circ} \mathrm{C}$ with $5 \% \mathrm{CO}_{2}$.

\section{Reagents}

Toyopearl-H65F (TOSH, Japan); Coomassie brilliant blue G-250, Ascorbic acid, and Bovine serum albumin (Aladdin, USA); Tris-(hydroxymethyl)-aminomethane (Tris), Ethylenediaminetetraacetic acid (EDTA), and Salicylic acid (Sinopharm Chemical Reagent Co., Ltd, China); 2,2-diphenyl-1-picrylhydrazyl (DPPH), Dextrans, and MTT [3-(4,5-dimethylthiazol-2-yl)-2,5-diphenyl tetrazolium bromide] (Sigma-Aldrich, USA); D-mannose, L-rhamnose, D-galactose, D-glucose, and D-arabinose (Chinese Materials Research Center, China); Antibodies against $\beta$-actin, $\mathrm{Bax}, \mathrm{Bcl}-2$, goat anti-rabbit IgG, and goat anti-mouse IgG (Cell Signaling Technology, USA). All other reagents used were of analytical grade.

\section{Extraction, fractionation, and purification of polysaccharide}

Dendrobium officinale dry powders were refluxed with petroleum ether at $70{ }^{\circ} \mathrm{C}$ for $2 \mathrm{~h}$, then with 20 volumes of $80 \%$ ethanol for $2 \mathrm{~h}$ at $90^{\circ} \mathrm{C}$ to remove polar constituents

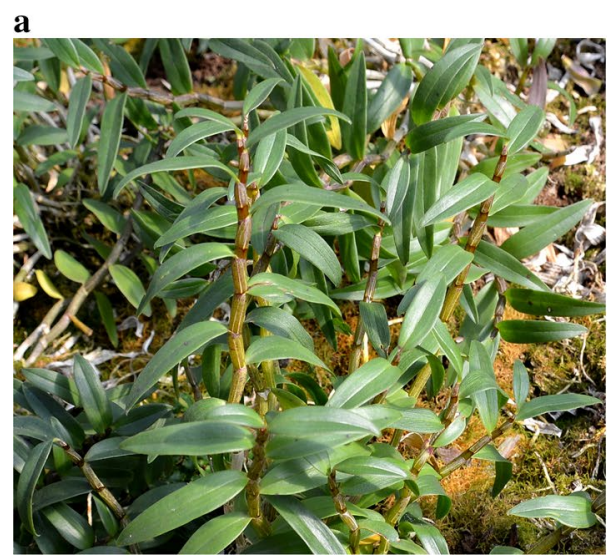

Fig. 1 Images of Dendrobium officinale (a), and its stems (b)

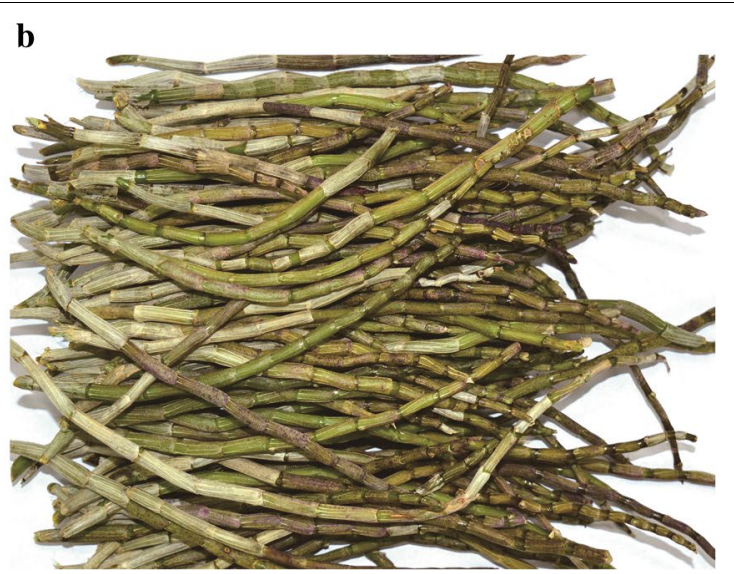


and filtered. The residue was extracted twice with 45 volumes of distilled water at $100{ }^{\circ} \mathrm{C}$ for $2 \mathrm{~h}$, then the aqueous was concentrated under vacuum and added with 4 volumes of $80 \%$ ethanol at $4{ }^{\circ} \mathrm{C}$ overnight, and centrifuged at $5000 \mathrm{rpm}$ for $10 \mathrm{~min}$. Subsequently, the precipitate was dissolved in distilled water and added with the Sevage reagent to remove protein present. The solution was precipitated with $80 \%$ ethanol and then lyophilized to obtain crude Dendrobium officinale polysaccharide (DOP) [13, 14].

The DOP (2 g) was dissolved in $100 \mathrm{ml}$ distilled water, then fractional precipitation with ethanol was applied to separate the solution [15], followed by different volumes of anhydrous ethanol $(66.67 \mathrm{ml}, 33.33 \mathrm{ml}, 50 \mathrm{ml}$ and $83.33 \mathrm{ml}$ ) were added to the solution to create a series of final concentration $(40 \%, 50 \%, 60 \%$ and $70 \%, v / v)$ of ethanol solution, successively. After the mixture was stored at $4{ }^{\circ} \mathrm{C}$ overnight, the four precipitates (DOP-40, DOP-50, DOP-60 and DOP-70) were collected by centrifugation and then freeze-dried, respectively (Fig. 2).

\section{Purification of polysaccharide fractions}

The four polysaccharide fractions were further purified by Toyopearl-H65F gel resin $(1.6 \times 80 \mathrm{~cm})$ and eluted with $0.2 \mathrm{~mol} / 1 \mathrm{NaCl}$ at a flow rate of $0.5 \mathrm{ml} / \mathrm{min}[16,17]$. Then the solution was collected in accordance with four elution peaks (DOP-40, DOP-50, DOP-60, and DOP-70),

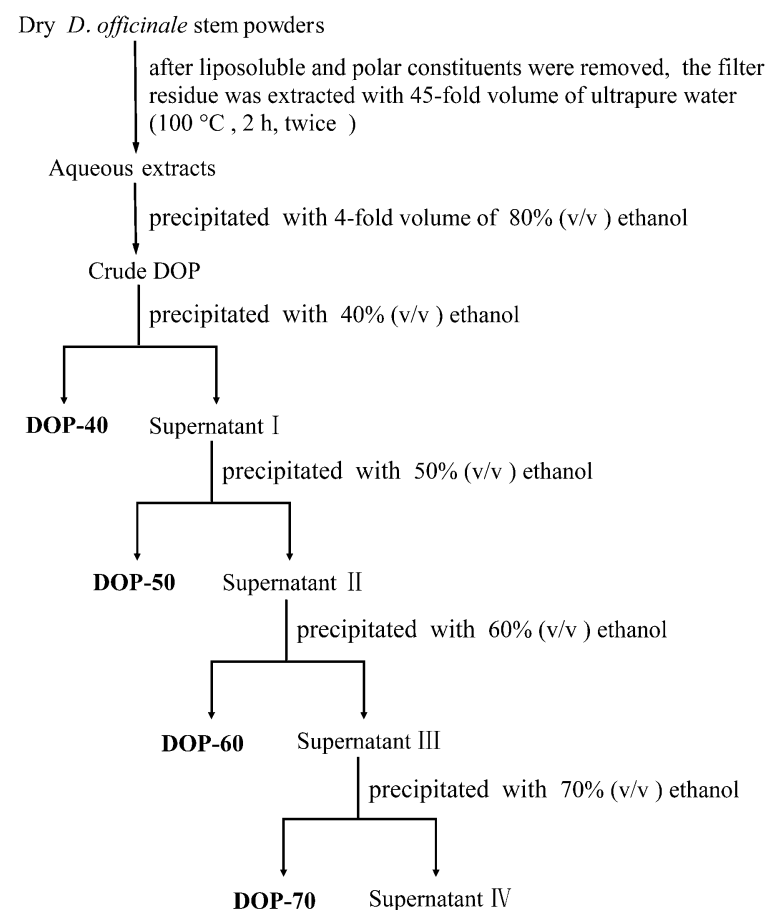

Fig. 2 Extraction and fractionation procedure of polysaccharide fractions from Dendrobium officinale stems concentrated, and dialyzed against distilled water for $48 \mathrm{~h}$, fresh distilled water was replaced every $4 \mathrm{~h}$, respectively. Finally, four dialyzed polysaccharide fractions solution were lyophilized for further study. The UV spectrophotometry was used to measure the $\mathrm{OD}$ value at $490 \mathrm{~nm}$.

\section{Determination of neutral sugar and protein contents}

The neutral sugar and protein contents of DOP-40, DOP50 , DOP-60, and DOP-70 were determined respectively by the improved phenol-sulfuric acid method taking glucose as the standard sample [18], and the Coomassie blue staining (G-250) assay taking BSA as the standard sample [19]. The experiment was repeated in triplicate $(n=5$ each time).

\section{Molecular weight determination}

The average molecular weights of DOP-40, DOP-50, DOP-60, and DOP-70 were determined by high performance gel permeation chromatography (HPGPC) using a TSK GMP ${ }_{W X L}$ chromatographic column $(7.8 \times 300 \mathrm{~mm}$, $2 \mu \mathrm{m}, \mathrm{TOSH}$, Japan). The mobile phase was $20 \mathrm{mM}$ $\mathrm{CH}_{3} \mathrm{COONH}_{4}$ with a flow rate of $0.8 \mathrm{ml} / \mathrm{min}$, and the standard curve was established using T-series dextran (MW: 1270, 5220, 11600, 48600, 80900, 273000, and $409800 \mathrm{Da})[20,21]$.

\section{Monosaccharide composition analysis}

The monosaccharide compositions of DOP-40, DOP50 , DOP-60, and DOP-70 were analyzed by HPLC equipped with a Kromasil 100-5C18 chromatographic column $(4.6 \times 250 \mathrm{~nm}, 5 \mu \mathrm{m}$, AKZO NOBEL, Sweden) [22]. The compositions of mobile phase were acetonitrile (solvent $\mathrm{A}$ ) and $0.1 \mathrm{M}$ aqueous $\mathrm{KH}_{2} \mathrm{PO}_{4}$ acetonitrile (solvent $\mathrm{B}$ ), the flow rate was $0.8 \mathrm{ml} / \mathrm{min}$, and the wavelength of detection was $250 \mathrm{~nm}$. Five monosaccharide standards (D-mannose, L-rhamnose, D-galactose, D-glucose, and D-arabinose) were used to establish standard curves, and the monosaccharide compositions and molar ratio of DOP-40, DOP-50, DOP-60, and DOP-70 were determined.

\section{Determination of antioxidant activities Reducing power assay}

The polysaccharide fractions (DOP-40, DOP-50, DOP60 , and DOP-70) were prepared into concentrations of $0.5 \mathrm{mg} / \mathrm{ml}, 1 \mathrm{mg} / \mathrm{ml}, 2 \mathrm{mg} / \mathrm{ml}, 3 \mathrm{mg} / \mathrm{ml}$ and $5 \mathrm{mg} / \mathrm{ml}$ with distilled water for antioxidant activities assays, ascorbic acid was used as the positive control, and each assay was repeated three times.

The reducing power of sample was determined according to the method with some modifications [23]. The system contained $2 \mathrm{ml}$ of $\mathrm{K}_{3} \mathrm{Fe}(\mathrm{CN})_{6}(1 \%, \mathrm{w} / \mathrm{v}), 2 \mathrm{ml}$ of 
sample solution, and $2 \mathrm{ml}$ of phosphate buffer $(0.2 \mathrm{~mol} / \mathrm{l}$, $\mathrm{pH}$ 6.6). After the mixed solution was incubated at $50{ }^{\circ} \mathrm{C}$ for $20 \mathrm{~min}, 2.5 \mathrm{ml}$ of trichloroacetic acid $(10 \%$, w/v) was added to the solution to stop the reaction, then the solution was centrifuged at $3000 \mathrm{rpm}$ for $15 \mathrm{~min}$, after $2 \mathrm{ml}$ of the supernatant was mixed with $2 \mathrm{ml}$ of distilled water and $1 \mathrm{ml}$ of ferric chloride $(0.1 \%, \mathrm{w} / \mathrm{v})$ for $10 \mathrm{~min}$ at room temperature. The absorbance representing the ability of the reducing power was measured at $700 \mathrm{~nm}$.

\section{Superoxide anion radical $\left(\mathrm{O}_{2}^{-}\right)$scavenging assay}

$\mathrm{O}_{2}{ }^{-}$scavenging activities of DOP-40, DOP-50, DOP-60, and DOP-70 were evaluated by pyrogallol autoxidation method, with slight innovation [24]. Four sample solutions were diluted with Tris- $\mathrm{HCl}$ buffer $(0.05 \mathrm{~mol} / \mathrm{l}, \mathrm{pH}$ 7.4) to form various mixed solutions $(0.5 \mathrm{mg} / \mathrm{ml}, 1 \mathrm{mg} /$ $\mathrm{ml}, 2 \mathrm{mg} / \mathrm{ml}, 3 \mathrm{mg} / \mathrm{ml}$, and $5 \mathrm{mg} / \mathrm{ml}$ ), and then $0.4 \mathrm{ml}$ of pyrogallic acid $(60 \mathrm{mM})$ was added to the mixture solutions at $25{ }^{\circ} \mathrm{C}$. The final mixture was shaken vigorously and incubated at $25{ }^{\circ} \mathrm{C}$ for 5 mines, and the absorbance of the reaction mixture was determined at $325 \mathrm{~nm}$. The $\mathrm{O}_{2}{ }^{-}$scavenging rate was calculated according to the following formula:

$$
\mathrm{O}_{2}^{-} \text {scavenging rate }(\%)=\left[1-\frac{\mathrm{A}_{1}}{\mathrm{~A}_{0}}\right] \times 100
$$

where $A_{1}$ is the absorbance of sample, and $A_{0}$ is the absorbance of blank (distilled water instead of sample solution).

\section{DPPH radical scavenging assay}

DPPH radical scavenging activities of DOP-40, DOP-50, DOP-60, and DOP-70 were determined according to a reported method with a few modifications [25]. DPPH powder was dissolved in anhydrous ethanol $(40 \mathrm{mg} / \mathrm{ml})$ as the stock solution. Then aliquots of $2 \mathrm{ml}$ of polysaccharide fraction samples solution were added to $2 \mathrm{ml}$ of DPPH stock solution in a cuvette and incubated for $20 \mathrm{~min}$ in the dark, and the absorption was determined at $517 \mathrm{~nm}$. The DPPH radical scavenging rate of polysaccharide fractions was expressed as the following equation:

$$
\text { DPPH radical scavenging rate }(\%)=\left[1-\frac{\mathrm{A}_{i}-\mathrm{A}_{j}}{\mathrm{~A}_{c}}\right] \times 100
$$

where $\mathrm{A}_{i}$ is the absorbance of the solution including $\mathrm{DPPH}$ and sample as the experimental group, $\mathrm{A}_{j}$ is the absorbance of the solution which contains DPPH and anhydrous ethanol as the background group, $\mathrm{A}_{c}$ is the absorbance of the anhydrous ethanol solution as the blank group.

\section{Hydroxyl radical scavenging assay}

Hydroxyl radical scavenging activities of DOP-40, DOP-50, DOP-60, and DOP-70 were performed with a reported method described [26]. Briefly, $2 \mathrm{ml}$ of $\mathrm{Fe}_{2} \mathrm{SO}_{4}$ (6 mM), $2 \mathrm{ml}$ of salicylic acid-ethanol $(6 \mathrm{mM})$ and $2 \mathrm{ml}$ of the four polysaccharide fractions were mixed thoroughly in the cuvette. After $10 \mathrm{~min}, 2 \mathrm{ml}$ of the $\mathrm{H}_{2} \mathrm{O}_{2}$ $(6 \mathrm{mM})$ was added to the mixture solution, the reaction solutions were incubated in $37^{\circ} \mathrm{C}$ thermostat water bath for $30 \mathrm{~min}$. The absorbance of solutions was measured at $510 \mathrm{~nm}$. The results were calculated by the following equation:

$$
\begin{aligned}
& \text { Hydroxyl radical scavenging rate (\%) } \\
& \qquad=\left[1-\frac{\mathrm{A}_{1}-\mathrm{A}_{2}}{\mathrm{~A}_{0}}\right] \times 100
\end{aligned}
$$

where $A_{1}$ is the absorbance of sample solution as the experimental group, $A_{2}$ is the absorbance of the mixture solution which distilled water instead of $\mathrm{H}_{2} \mathrm{O}_{2}$ as the background group, $\mathrm{A}_{0}$ is the absorbance of the mixture solution which distilled water instead of the sample as the blank group.

\section{Anticancer activity assay in HepG2 cells Influence of polysaccharide fractions on HepG2 cell viability} The anticancer effect of polysaccharide fractions were examined by MTT assay. HepG2 cells $\left(5 \times 10^{3}\right.$ cells/ well) were seeded in 96-well plates for $24 \mathrm{~h}$, then treated with DOP-40, DOP-50, DOP-60, and DOP-70 (25 mg/ $\mathrm{ml}, 50 \mathrm{mg} / \mathrm{ml}, 100 \mathrm{mg} / \mathrm{ml}, 200 \mathrm{mg} / \mathrm{ml}$, and $400 \mathrm{mg} / \mathrm{ml}$ ) for $24 \mathrm{~h}$ and $48 \mathrm{~h}$. After adding $100 \mu \mathrm{l}$ of MTT reagent $(0.5 \mathrm{mg} / \mathrm{ml})$ for $4 \mathrm{~h}$ incubation, the medium was replaced with $150 \mathrm{ml}$ DMSO to dissolve the formazan. The absorbance value of the experimental group $\left(\mathrm{A}_{\text {experimental }}\right)$ and control group $\left(\mathrm{A}_{\text {control }}\right)$ were read at $490 \mathrm{~nm}$ by Victor $\mathrm{X} 3$ (PerkinElmer, USA) and inhibition rate was calculated as follows:

$$
\text { Inhibition rate }(\%)=\left(1-\frac{\mathrm{A}_{\text {experimental }}}{\mathrm{A}_{\text {control }}}\right) \times 100
$$

\section{Western blot analysis}

HepG2 cells $\left(2.5 \times 10^{5}\right.$ cells/well $)$ were seeded in 6-well plates, and treated with $400 \mathrm{mg} / \mathrm{ml}$ DOP-40, DOP-50, DOP-60, and DOP-70 for $48 \mathrm{~h}$, respectively. The protein was lysed and harvested by RIPA buffer (1\% PMSF). Then according to the standard western blot protocol, the samples were incubated with the primary antibodies ( $\beta$-actin, $\mathrm{Bax}$ and $\mathrm{Bcl}$ ) for overnight at $4{ }^{\circ} \mathrm{C}$. After incubated with the corresponding HRP-labeled secondary antibody (Goat anti-mouse IgG or anti-rabbit IgG) at room 
temperature for $1 \mathrm{~h}$. The hybridization signal of the protein band was examined using ECL detection reagents.

\section{Statistical analysis}

All the experimental data were statistically analyzed with SPSS 19.0 software and expressed as mean \pm standard deviation (SD) by GraphPad Prism 6.0 software. *p $<0.05$ and ${ }^{* *} \mathrm{p}<0.01$ are determined as significance.

\section{Results}

\section{Extraction and purification of polysaccharide fractions}

Four new Dendrobium officinale polysaccharides (DOP40, DOP-50, DOP-60, and DOP-70) were successively obtained from $10 \mathrm{mg} / \mathrm{ml}$ crude DOP solution by fractional precipitation with final concentrations $(40 \%, 50 \%$, $60 \%$ and $70 \%, v / v$ ) of ethanol solution (Fig. 2), and further purified by Toyopearl-H65F column chromatography. As the results showed (Fig. 3a-d), elution curves of four fractions produced symmetrical single elution peak eluted with $0.2 \mathrm{~mol} / \mathrm{l} \mathrm{NaCl}$ solutions. The yields of DOP40 , DOP-50, DOP-60, and DOP-70 from the crude DOP were $59.0 \%, 23.8 \%, 7.5 \%$, and $5.0 \%$, respectively.

\section{Physicochemical properties analysis}

The physicochemical properties of DOP-40, DOP-50, DOP-60, and DOP-70 from Dendrobium officinale stems were listed in Table 1. The protein content of each fraction were $1.68 \%, 1.12 \%, 0.03 \%$, and $0.34 \%$, the neutral sugar content of each fraction were $8.32 \%, 10.43 \%$, $21.33 \%$, and $6.82 \%$, respectively. Among them, DOP-70 contained the lowest content of protein, and the highest content of neutral sugar.

The molecular weight of polysaccharide was a representative of similar polymer chain length distributed on average. HPGPC was applied to analyze the molecular weight, and the Table 1 indicated that the average molecular weights of DOP-40, DOP-50, DOP-60, and DOP-70

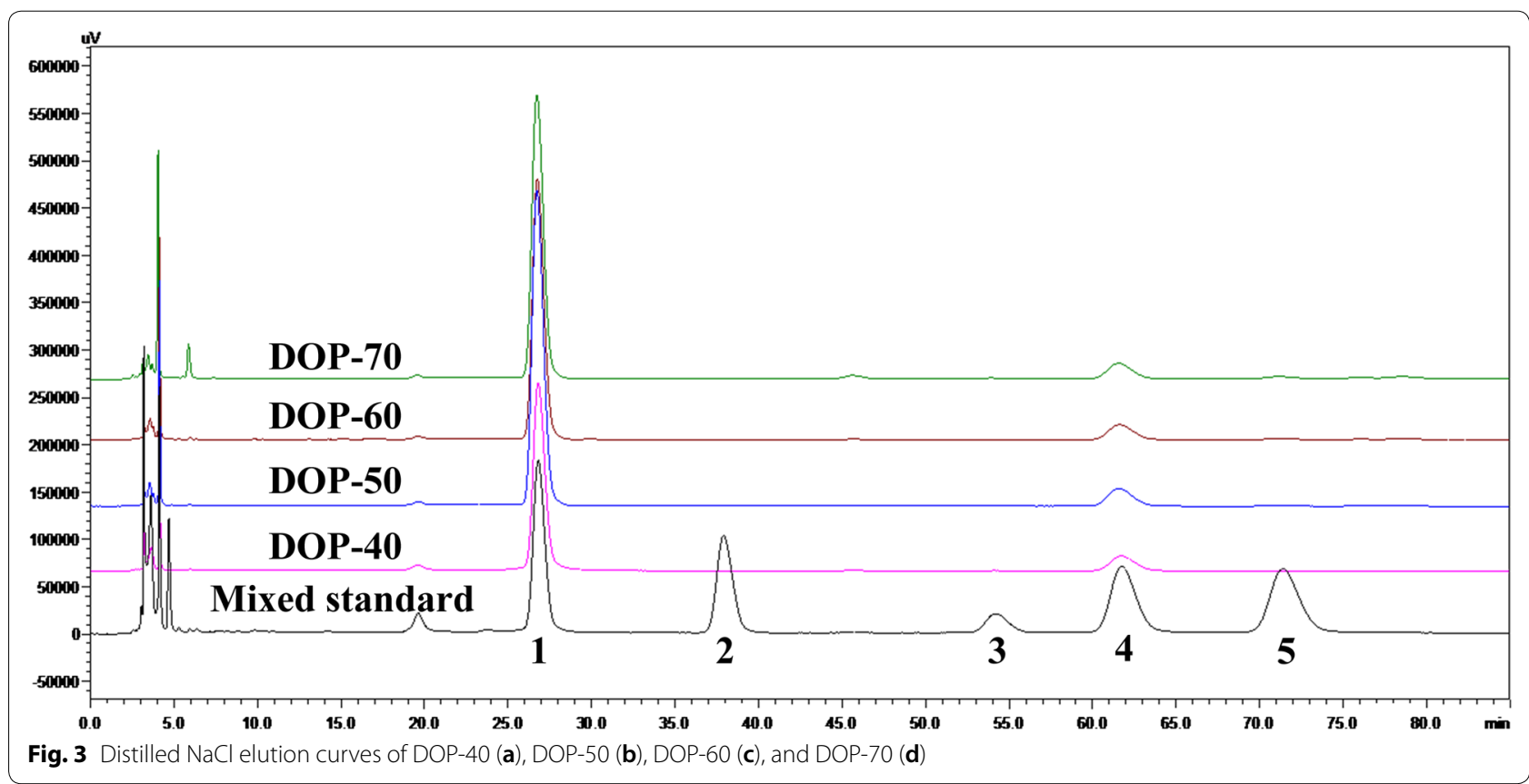

Table 1 The yield and physicochemical properties of polysaccharide fractions from Dendrobium officinale stems

\begin{tabular}{|c|c|c|c|c|}
\hline Samples & DOP-40 & DOP-50 & DOP-60 & DOP-70 \\
\hline Yield (wt\%) & $59.31 \pm 0.21$ & $23.82 \pm 0.23$ & $7.55 \pm 0.31$ & $5.25 \pm 0.09$ \\
\hline Neutral sugar content (wt\%) & $18.38 \pm 1.51$ & $28.38 \pm 1.53$ & $13.67 \pm 2.78$ & $9.38 \pm 0.71$ \\
\hline Protein content (wt\%) & $4.28 \pm 0.06$ & $1.68 \pm 0.09$ & $1.12 \pm 0.03$ & $0.34 \pm 0.02$ \\
\hline Molecular weight (kDa) & $999 \pm 0.03$ & $657 \pm 0.02$ & $243 \pm 0.02$ & $51 \pm 0.01$ \\
\hline \multicolumn{5}{|l|}{ Monosaccharide composition } \\
\hline D-Mannose/D-Glucose (molar ratio) & $6.32 \pm 0.15$ & $8.67 \pm 0.16$ & $8.34 \pm 0.13$ & $8.82 \pm 0.05$ \\
\hline
\end{tabular}


were estimated to be $999 \mathrm{kDa}, 657 \mathrm{kDa}, 243 \mathrm{kDa}$ and $50.3 \mathrm{kDa}$, respectively.

In this study, the monosaccharide compositions of the four fractions were measured by HPLC, and the results (Fig. 4) were shown that the peaks of all samples were symmetrical and sharp with good sensitivity. According to the mixed standard monosaccharides, four fractions had the same main monosaccharides composition (D-mannose and D-glucose) in different molar ratios of 6.32:1, 8.67:1, 8.34:1, and 8.82:1 respectively. Obviously, abundant D-mannose was found in all the fractions.

\section{Antioxidant activity in vitro}

\section{Reducing power}

The reducing power of DOP-40, DOP-50, DOP-60, and DOP-70 were measured at $700 \mathrm{~nm}$, and the results were shown in Fig. 5a. The reducing powers of DOP-40, DOP60 , and DOP-70 were very close and entangled from 0.5 to $5 \mathrm{mg} / \mathrm{ml}$, except DOP-50. Among them, DOP-40, DOP-60 and DOP-70 deliberated higher reducing power than DOP-50. Meanwhile, the absorbance of DOP-70 and ascorbic acid were 2.317 and 3.033 at $5 \mathrm{mg} / \mathrm{ml}$, which implied that the reducing power of DOP-70 was $76.4 \%$ of that of the positive control (ascorbic acid).
Superoxide anion radical $\left(\mathrm{O}_{2}^{-}\right)$scavenging activity

The scavenging abilities of DOP-40, DOP-50, DOP-60, and DOP-70 for $\mathrm{O}_{2}{ }^{-}$were shown in Fig. 5b. Obviously the $\mathrm{O}_{2}{ }^{-}$scavenging activities of four fractions increased with increasing concentrations, DOP-70 exhibited the higher scavenging ability $\left(\mathrm{IC}_{50}=2625.6 \mu \mathrm{g} / \mathrm{ml}\right)$ than DOP-40, DOP-50 and DOP-60, but lower than the positive control, and the order was DOP-70 > DOP-40 > DOP$60>$ DOP-50. At $5 \mathrm{mg} / \mathrm{ml}$, the $\mathrm{O}_{2}{ }^{-}$scavenging rates of DOP-40, DOP-50, DOP-60 and DOP-70 were $56.5 \%$, $25.6 \%, 47.6 \%$, and $65.3 \%$, respectively.

\section{$D P P H$ radical scavenging activity}

The results of this study indicated four fractions exhibited strong scavenging activities against DPPH radicals in a dose-dependent pattern (Fig. 5c). At $5 \mathrm{mg} / \mathrm{ml}$, the scavenging rates of DOP-40, DOP-50, DOP-60, and DOP-70 were $55.3 \%, 32.5 \%, 61.6 \%$, and $70.3 \%$. DOP70 showed the strongest effect on DPPH radicals with the lowest $\mathrm{IC}_{50}$ value of $2395.8 \mu \mathrm{g} / \mathrm{ml}$ among four fractions, while DOP-50 still exhibited the weakest scavenging capacity. And their $\mathrm{IC}_{50}$ decreased in the order of DOP-70 $<$ DOP- $60<$ DOP- $40<$ DOP- 50 .
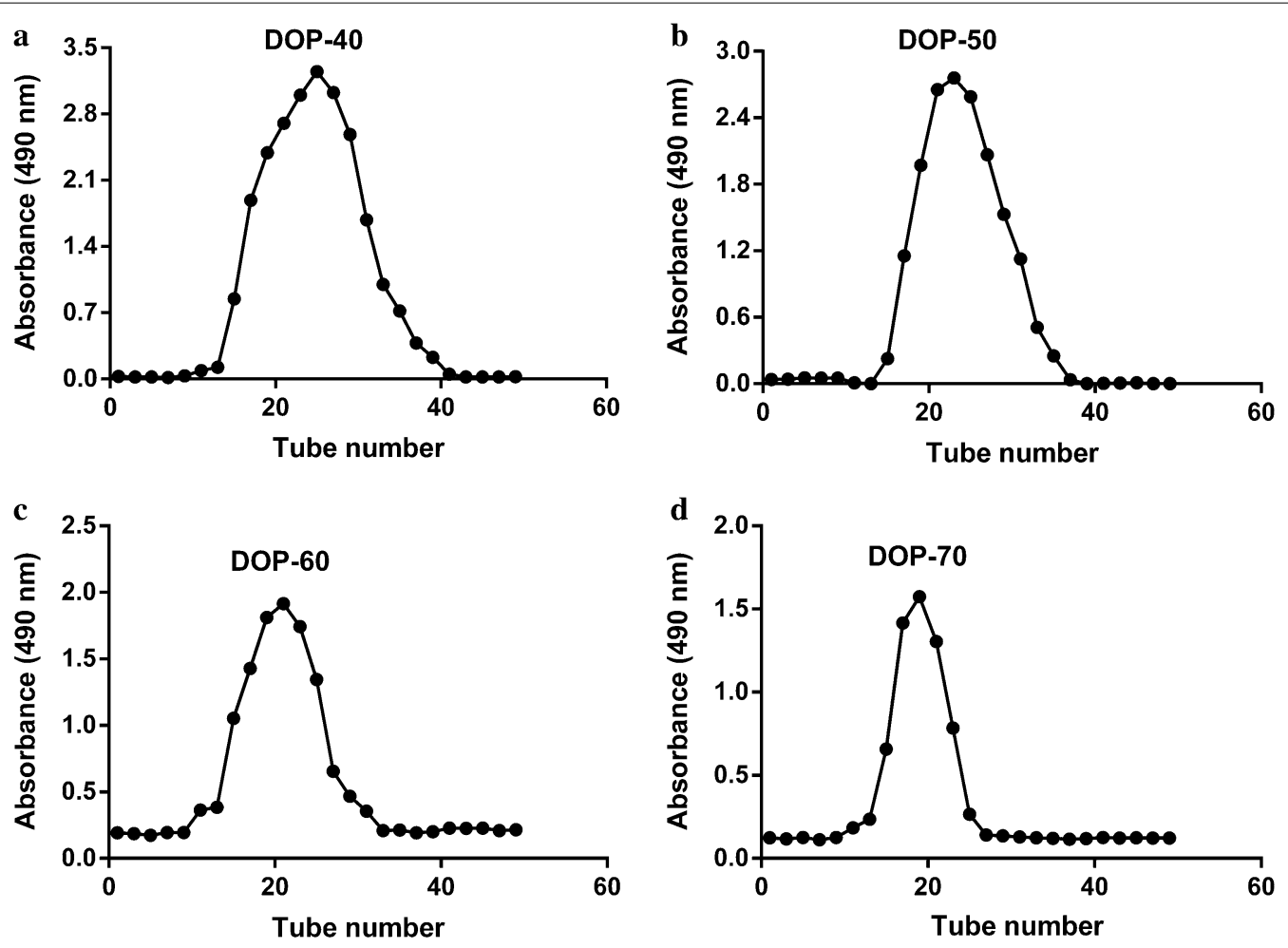

Fig. 4 HPLC profile of mixed monosaccharide standards (1-mannose, 2-rhamnose, 3-galactose, 4-glucose, and 5-arabinose), DOP-40, DOP-50, DOP-60, and DOP-70 

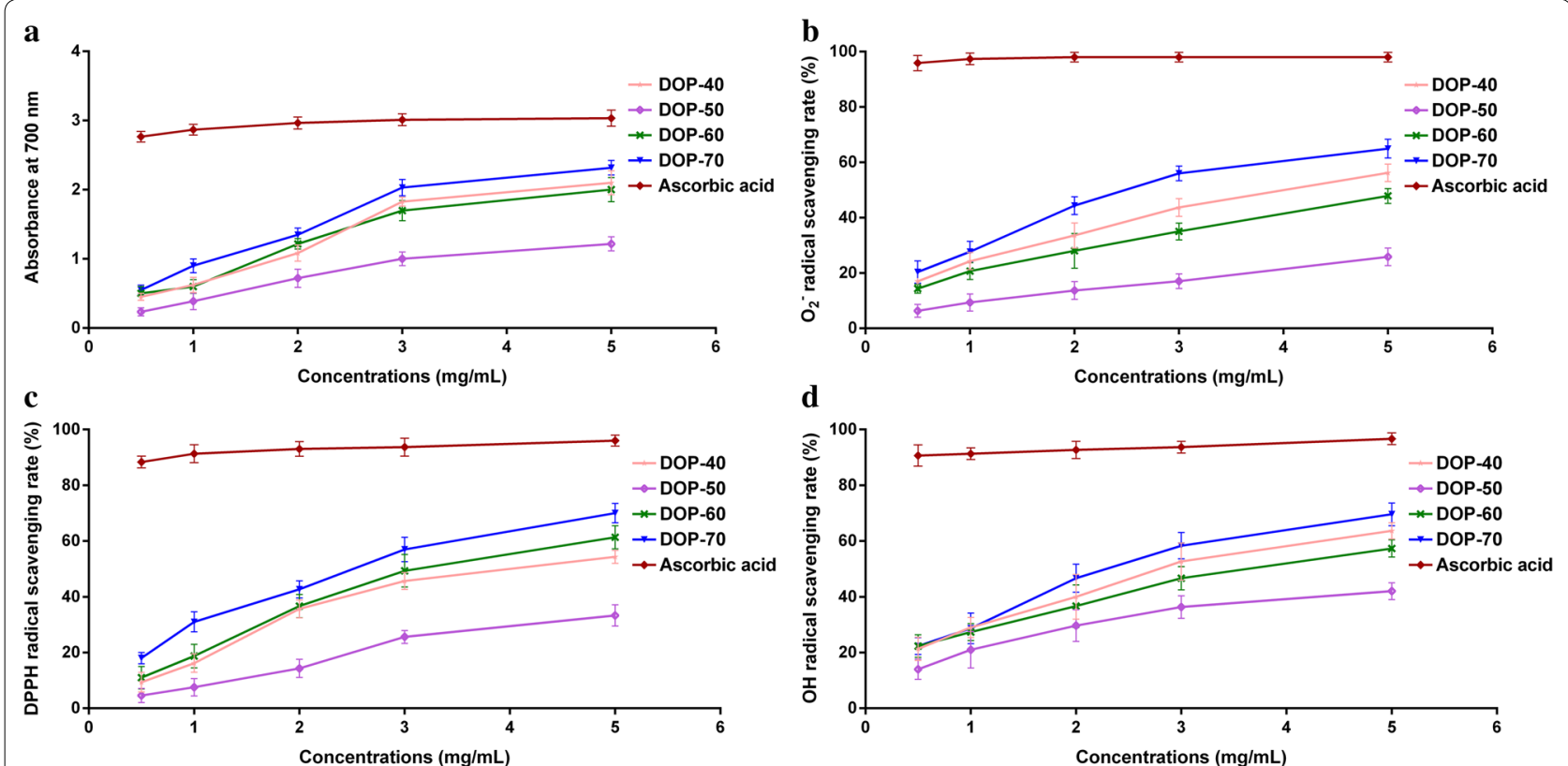

Fig. 5 Scavenging activities on the reducing power assay (a), superoxide anion radical (b), DPPH radical (c), and hydroxyl radical (d) for DOP-40, DOP-50, DOP-60, and DOP-70

\section{Hydroxyl radical scavenging activity}

As illustrated in Fig. 5d, the hydroxyl radical scavenging activities of DOP-40, DOP-50, DOP-60, and DOP-70 increased gradually as the concentration increased from 0.5 to $5 \mathrm{mg} / \mathrm{ml}$. And their scavenging rates increased in the order was: DOP-70 $>$ DOP-40 $>$ DOP-60 $>$ DOP -50 , with their $\mathrm{IC}_{50}$ values of $2081.7 \mu \mathrm{g} / \mathrm{ml}, 2837.7 \mu \mathrm{g} / \mathrm{ml}$, $3385.3 \mu \mathrm{g} / \mathrm{ml}$ and $5803.8 \mu \mathrm{g} / \mathrm{ml}$, respectively. At $5 \mathrm{mg} /$ $\mathrm{ml}$ of DOP-70, the hydroxyl radical scavenging rate was 69.5\% showed the highest effect on hydroxyl radical, while the scavenging rate of DOP-40, DOP-50, and DOP60 was $63.3 \%, 42.2 \%$, and $58.6 \%$, respectively. The results were consistent with the results of reducing power, $\mathrm{O}_{2}{ }^{-}$, and DPPH radical scavenging assays.

\section{Anticancer activity in HepG2 cells \\ HepG2 cell growth analysis}

The effects of DOP-40, DOP-50, DOP-60, and DOP-70 on the growth of the HepG2 cells were first determined by MTT assay. As indicated in Fig. 6a, b, DOP-40, DOP60 , and DOP-70 significantly inhibited the cell proliferation of HepG2 cells in both dose- and time-dependent manner, particularly at a concentration greater than $200 \mu \mathrm{g} / \mathrm{ml}$ at $48 \mathrm{~h}$. In addition, $400 \mu \mathrm{g} / \mathrm{ml}$ DOP-70 markedly increased the inhibition rate by $34.75 \%$ at $24 \mathrm{~h}$ and $61.36 \%$ at $48 \mathrm{~h}$, while the inhibition rates of $400 \mu \mathrm{g} / \mathrm{ml}$ of DOP-40, DOP-50, and DOP-60 were $26.63 \%, 18.31 \%$ and $25.73 \%$ at $24 \mathrm{~h}$ and $53.56 \%, 30.36 \%$ and $47.38 \%$ at $48 \mathrm{~h}$, respectively. So effective concentrations of $400 \mu \mathrm{g} / \mathrm{ml}$ and incubation period of $48 \mathrm{~h}$ were used in subsequent experiments.

\section{Apoptosis-related protein expressions of $\mathrm{Bax}, \mathrm{BCl}-2$}

In order to clarify the mechanisms underlying the inhibition of HepG2 cells by DOP-40, DOP-50, DOP-60, and DOP-70, the protein levels of Bax and Bcl-2 were measured by western blotting. As shown in Fig. $6 \mathrm{c}-\mathrm{f}$, the level of anti-apoptotic Bcl-2 was significantly decreased in response to treatment with DOP-40, DOP-60, and DOP70 at a concentration of $400 \mu \mathrm{g} / \mathrm{ml}$ for $48 \mathrm{~h}$, except DOP50. Meanwhile, DOP-40, DOP-50, DOP-60, and DOP-70 treatment noticeably increased the pro-apoptotic Bax expression compared to the control group, especially DOP-70. The results showed that DOP-40, DOP-60, and DOP-70 induced apoptosis in HepG2 cells through the Bax- and Bcl-2-dependent pathway.

\section{Discussion}

Dendrobium officinale stem contains numerous natural polysaccharides, however different isolation and purification methods have important influence on the molecular weight, monosaccharide composition and bioactivity of Dendrobium officinale polysaccharides (DOP). Fractional precipitation with ethanol is a simple and rapid method to purify biologically active polysaccharides from crude plant extracts [27]. In this study, we first extracted the crude DOP with hot water extraction-alcohol 


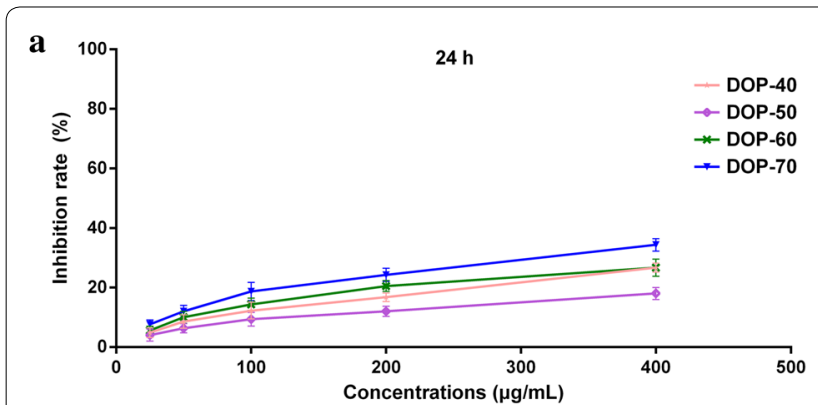

c

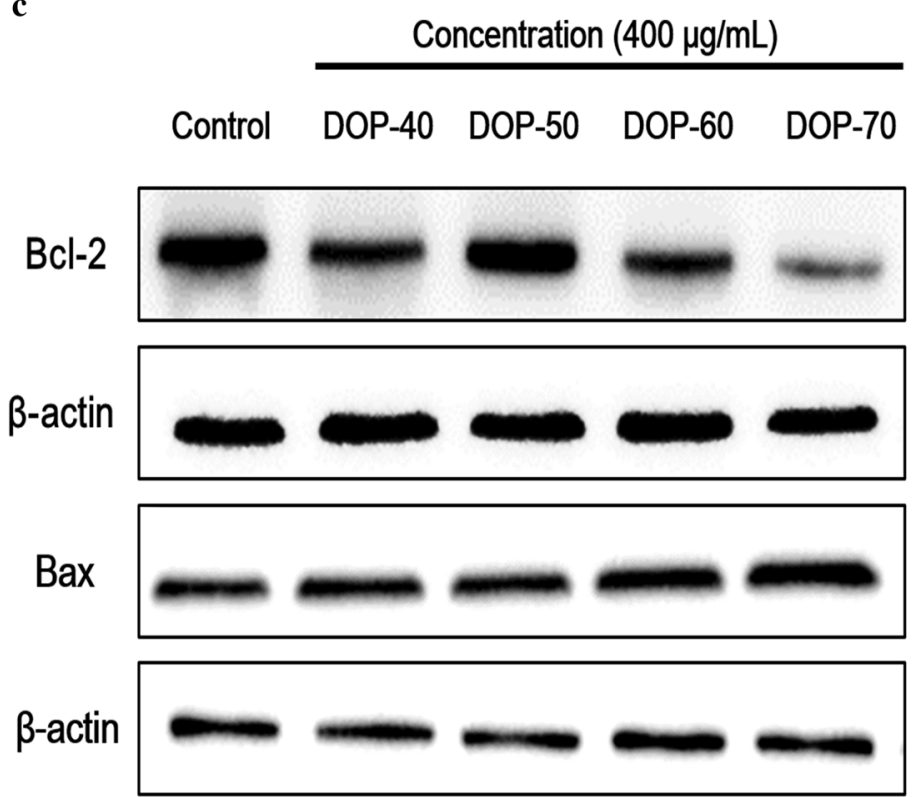

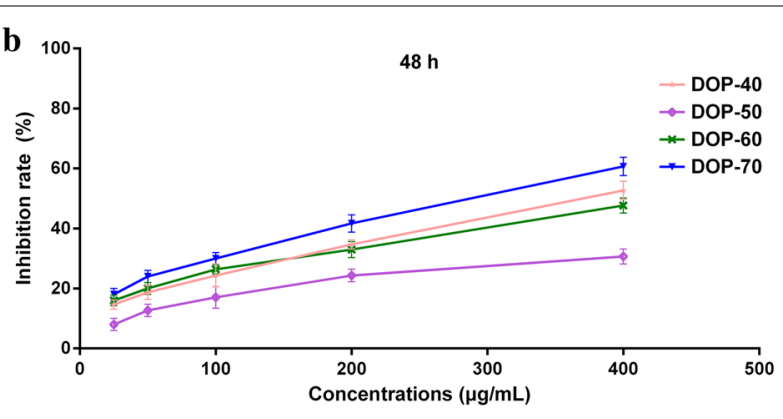

d

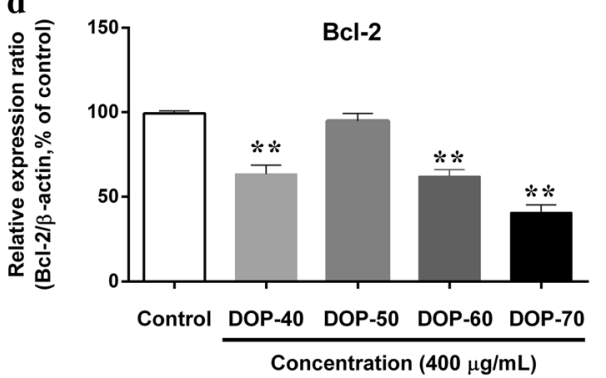

45

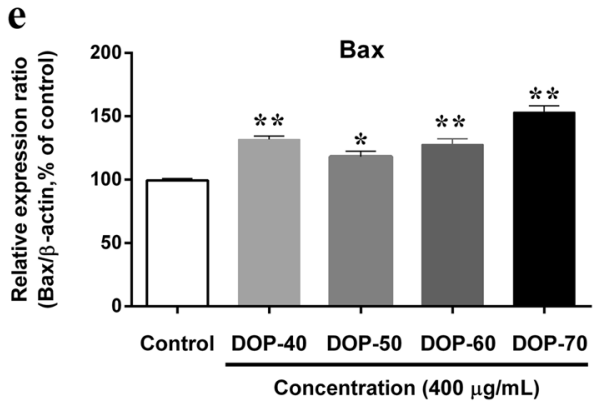

Fig. 6 Growth inhibition analysis of HepG2 cells treated with DOP-40, DOP-50, DOP-60, and DOP-70 for $24 \mathrm{~h}$ (a) and $48 \mathrm{~h}$ (b) by MTT assay. The protein levels of Bcl-2 (c, e) and Bax (c, $\mathbf{f})$ in HepG2 cells treated with DOP-40, DOP-50, DOP-60, and DOP-70 (400 $\mu \mathrm{g} / \mathrm{ml})$ for $48 \mathrm{~h}$ were analyzed by western blotting. The bar graphs (mean \pm SD) and representative images are shown. ${ }^{*} p<0.05 ;{ }^{* *} p<0.01$ compared with the control group

precipitation method, then four polysaccharide fractions (DOP-40, DOP-50, DOP-60 and DOP-70) were isolated from the crude DOP via ethanol fractional precipitation method. Importantly, the ethanol concentration is also closely associated with the molecular weight and bioactivity of the polysaccharide fractions. As our results showed, the average molecular weights of DOP-40, DOP50 , DOP-60, and DOP-70, precipitated with final ethanol concentration of $40 \%, 50 \%, 60 \%$ and $70 \%$, were $999 \mathrm{kDa}$, $657 \mathrm{kDa}, 243 \mathrm{kDa}$ and $50.3 \mathrm{kDa}$, respectively. Obviously, in the aqueous solution of polysaccharide, the alcohol content is gradually increased by adding ethanol, which can precipitate Dendrobium officinale polysaccharide fractions of molecular weight from large to small.

The monosaccharide composition of polysaccharide played a critical role in the biological activity of polysaccharide [28]. HPLC was applied to determine the monosaccharide composition of DOP-40, DOP-50, DOP-60, and DOP-70, and the results indicated that four fractions mainly consisted of D-mannose and D-glucose in different molar ratios. Interestingly, from the HPLC profile analysis, the content of D-mannose was much higher than D-glucose in all fractions.

$\mathrm{O}_{2}^{-}$was the first oxygen free radical in the body, and the precursor of other reactive oxygen species, which could lead to cell death, DNA and membrane degradation, and enzyme inactivation [29]. As the $\mathrm{O}_{2}{ }^{-}$was toxic, the $\mathrm{O}_{2}{ }^{-}$scavenging ability was quite essential for the antioxidant defense in vivo. On the one hand, the reducing power as the important indicator of potential antioxidant activity may directly reflect the reduction of $\mathrm{Fe}^{3+}$ to $\mathrm{Fe}^{2+}$ by donating an electron [30]. On the other hand, DPPH, as hydrogen donors, owns a characteristic absorption of proton free radical in spectrophotometric method, so the DPPH assay has been extensively used to evaluate antioxidant activity of natural products [31]. 
Furthermore, the hydroxyl radical was very dangerous compound to the health, which was closely related to several neurological autoimmune diseases, and could damage nucleic acid, amino acids and other macromolecules [32]. In our current study, all antioxidant activity assays indicated that DOP-40, DOP-60, and DOP-70 possessed strong reduction ability and high scavenging activity of $\mathrm{O}_{2}{ }^{-}$, hydroxyl and DPPH radicals in a dose-dependent manner. Among them, DOP-70 always showed the strongest antioxidant activity, and the scavenging activities of DOP-40 and DOP-60 were obviously better than that of DOP- 50 .

Anticancer effects of the four polysaccharide fractions on HepG2 cells were first evaluated using the MTT assay. The results demonstrated that DOP-70 always exhibited higher inhibition rate of HepG2 cells than DOP-40, DOP-50, and DOP-60 at the concentration of $400 \mu \mathrm{g} /$ $\mathrm{ml}$ for $24 \mathrm{~h}$ and $48 \mathrm{~h}$. Bax and Bcl-2 are the essential members of $\mathrm{Bcl}-2$ family proteins, which can adjust cell growth and cell death through regulating apoptotic pathway [33]. Furthermore, western blot analysis showed that DOP-40, DOP-60, and DOP-70 decreased the expression level of Bcl-2 and increased the expression level of Bax in HepG2 cells, and DOP-70 had the strongest anticancer effect among them. Above all, the anticancer activities of four polysaccharide fractions were quite similar to their antioxidant effect, and these results also implied that DOP-40, DOP-60, and DOP-70 possessed strong antioxidant and anticancer activities.

\section{Conclusion}

In our current study, four polysaccharide fractions were successfully extracted and purified from Dendrobium officinale stems via fractional precipitation with ethanol. The results suggested that DOP-40, DOP-60, and DOP-70 could be developed as promising natural drug therapies or health foods with their antioxidant and anticancer activities.

\footnotetext{
Abbreviations

DOP: Dendrobium officinale polysaccharides; DMEM: Dulbecco's modified Eagle's medium; FBS: fetal bovine serum; MTT: [3-(4, 5-dimethylthiazol-2-yl)2,5-diphenyl tetrazolium bromide]; MW: molecular weights; HPGPC: high performance gel permeation chromatography; HPLC: high performance liquid chromatography; DPPH: (1,1-diphenyl-2-picryl-hydrazl); $\mathrm{O}_{2}^{-}$: superoxide anion radical; wt\%: weight percentage; PMSF: phenylmethylsulfonyl fluoride; ECL: enhanced chemiluminescence.

\section{Authors' contributions}

GW conceived and designed the experiments. SPX coordinated the experiments and contributed to data interpretation and manuscript writing. XFZ and HNK purified Dendrobium officinale polysaccharide fractions and determined its physicochemical properties and antioxidant activity assay. YCH and $J$ carried out the cell experiments. All authors read and approved the final manuscript.
}

\begin{abstract}
Author details
${ }^{1}$ School of Pharmaceutical Science, Guangzhou University of Chinese Medicine, Guangzhou 510006, China. ${ }^{2}$ The First Affiliated Hospital of Guangzhou University of Chinese Medicine, Guangzhou 510006, China.
\end{abstract}

\section{Competing interests}

All authors declare that they have no competing interests.

Ethics approval and consent to participate

This article does not contain any studies with human participants or animals performed by any of the author.

\section{Funding}

This project was supported by support by the Special Foundation of 2015 and 2017 High Level University Construction (No. 2050205, A1-AFD018171Z11024).

\section{Informed consent}

Informed consent was obtained from all individual participants included in the study.

\section{Publisher's Note}

Springer Nature remains neutral with regard to jurisdictional claims in published maps and institutional affiliations.

Received: 23 April 2018 Accepted: 19 September 2018

Published online: 25 September 2018

\section{References}

1. Ding X, Wang Z, Zhou K, Xu L, Xu H, Wang Y (2003) Allele-specific primers for diagnostic PCR authentication of Dendrobium officinale. Planta Med 69:587-588

2. Hou B, Luo J, Zhang Y, Niu Z, Xue Q, Ding X (2017) Iteration expansion and regional evolution: phylogeography of Dendrobium officinale and four related taxa in southern China. Sci Rep 7:43525

3. Liu XF, Zhu J, Ge SY, Xia LJ, Yang HY, Qian YT, Ren FZ (2011) Orally administered Dendrobium officinale and its polysaccharides enhance immune functions in BALB/c mice. Nat Prod Commun 6:867-870

4. Luo QL, Tang ZH, Zhang XF, Zhong YH, Yao SZ, Wang LS, Lin CW, Luo $X$ (2016) Chemical properties and antioxidant activity of a watersoluble polysaccharide from Dendrobium officinale. Int J Biol Macromol 89:219-227

5. Zhao Y, Liu Y, Lan XM, Xu GL, Sun YZ, Li F, Liu HN (2016) Effect of Dendrobium officinale extraction on gastric carcinogenesis in rats. Evid Based Complement Alternat Med 2016:1213090

6. Tang H, Zhao T, Sheng Y, Zheng T, Fu L, Zhang Y (2017) Dendrobium officinale Kimura et Migo: a review on its ethnopharmacology, phytochemistry, pharmacology, and industrialization. Evid Based Complement Alternat Med 2017:7436259

7. Feng S, Jiao K, Guo H, Jiang M, Hao J, Wang H, Shen C (2017) Succinylproteome profiling of Dendrobium officinale, an important traditional Chinese orchid herb, revealed involvement of succinylation in the glycolysis pathway. BMC Genomics 18:598

8. Huang K, Li Y, Tao S, Wei G, Huang Y, Chen D, Wu C (2016) Purification, characterization and biological activity of polysaccharides from Dendrobium officinale. Molecules 21:701

9. Xiang L, Sze CWS, Ng TB, Tong Y, Shaw PC, Tang CWS, Zhang YBK (2013) Polysaccharides of Dendrobium officinale inhibit TNF-alpha-induced apoptosis in A-253 cell line. Inflamm Res 62:313-324

10. Xie SZ, Liu B, Zhang DD, Zha XQ, Pan LH, Luo JP (2016) Intestinal immunomodulating activity and structural characterization of a new polysaccharide from stems of Dendrobium officinale. Food Funct 7:2789-2799

11. Shen YB, Song X, Chen YS, Li L, Sun J, Huang CH, Ou SY, Zhang H (2017) Effects of sorghum, purple rice and rhubarb rice on lipids status and antioxidant capacity in mice fed a high-fat diet. Food Funct 39:103-111

12. Xu J, Yue RQ, Liu J, Ho HM, Yi T, Chen HB, Han QB (2014) Structural diversity requires individual optimization of ethanol concentration in polysaccharide precipitation. Int J Biol Macromol 67:205-209 
13. Zeid AHA, Aboutabl EA, Sleem AA, El-Rafie HM (2014) Water soluble polysaccharides extracted from Pterocladia capillacea and Dictyopteris membranacea and their biological activities. Carbohydr Polym 113:62-66

14. Nunes FM, Coimbra MA (2002) Chemical characterization of the highmolecular-weight material extracted with hot water from green and roasted robusta coffees as affected by the degree of roast. J Agric Food Chem 50:7046-7052

15. Li H, Dai Q, Ren J, Jian L, Peng F, Sun R, Liu G (2016) Effect of structural characteristics of corncob hemicelluloses fractionated by graded ethanol precipitation on furfural production. Carbohydr Polym 136:203-209

16. Chun H, Shin DH, Hong BS, Cho HY, Yang HC (2001) Purification and biological activity of acidic polysaccharide from leaves of Thymus vulgaris L. Biol Pharm Bull 24:941-946

17. Wang J, Lian P, Yu Q, Wei J, Kang WY (2017) Purification, characterization and procoagulant activity of polysaccharides from Angelica dahurice roots. Chem Cent J 11:17

18. Zhang $\mathrm{CH}$, Yun YH, Zhang ZM, Liang YZ (2016) Simultaneous determination of neutral and uronic sugars based on UV-vis spectrometry combined with PLS. Int J Biol Macromol 87:290-294

19. Grintzalis K, Georgiou CD, Schneider YJ (2015) An accurate and sensitive Coomassie Brilliant Blue G-250-based assay for protein determination. Anal Biochem 480:28-30

20. Wang L, Wang C, Gao X, Xu N, Lin L, Zhao H, Jia S, Jia L (2015) Purification, characterization and anti-aging capacity of mycelia zinc polysaccharide by Lentinus edodes SD-08. BMC Complement Altern Med 15:111

21. Liu MC, Yang SJ, Hong D, Yang JP, Liu M, Lin Y, Huang CH, Wang CJ (2016) A simple and convenient method for the preparation of antioxidant peptides from walnut (Juglans regia L.) protein hydrolysates. Chem Cent J 10:39

22. Wu X, Jiang W, Lu J, Yu Y, Wu B (2014) Analysis of the monosaccharide composition of water-soluble polysaccharides from Sargassum fusiforme by high performance liquid chromatography/electrospray ionisation mass spectrometry. Food Chem 145:976-983

23. Kayani WK, Dilshad E, Ahmed T, Ismail H, Mirza B (2016) Evaluation of Ajuga bracteosa for antioxidant, anti-inflammatory, analgesic, antidepressant and anticoagulant activities. BMC Complement Altern Med 16:375

24. Du N, Sheng L, Liu Z, Hu X, Xu H, Chen S (2013) The binding characteristics of isoniazid with copper-zinc superoxide dismutase and its effect on enzymatic activity. Chem Cent J 7:97

25. Okoh SO, Iweriegbor BC, Okoh OO, Nwodo UU, Okoh Al (2016) Bactericidal and antioxidant properties of essential oils from the fruits Dennettia tripetala G. Baker. BMC Complement Altern Med 16:486

26. Moore J, Yin JJ, Yu LL (2006) Novel fluorometric assay for hydroxyl radical scavenging capacity (HOSC) estimation. J Agric Food Chem 54:617-626

27. Yang XB, Zhao Y, Yang Y, Ruan $Y$ (2008) Isolation and characterization of immunostimulatory polysaccharide from an herb tea, Gynostemma pentaphyllum Makino. J Agric Food Chem 56:6905-6909

28. Wang QC, Zhao X, Pu JH, Luan XH (2016) Influences of acidic reaction and hydrolytic conditions on monosaccharide composition analysis of acidic, neutral and basic polysaccharides. Carbohydr Polym 143:296-300

29. Villamena FA, Xia S, Merle JK, Lauricella R, Tuccio B, Hadad CM, Zweier JL (2007) Reactivity of superoxide radical anion with cyclic nitrones: role of intramolecular $\mathrm{H}$-bond and electrostatic effects. J Am Chem Soc 129:8177-8191

30. Fernando CD, Soysa P (2016) Evaluation of hepatoprotective activity of Eriocaulon quinquangulare in vitro using porcine liver slices against ethanol induced liver toxicity and free radical scavenging capacity. BMC Complement Altern Med 16:74

31. Liu J, Li X, Lin J, Li Y, Wang T, Jiang Q, Chen D (2016) Sarcandra glabra (Caoshanhu) protects mesenchymal stem cells from oxidative stress: a bioevaluation and mechanistic chemistry. BMC Complement Altern Med 16:423

32. Rohrer F, Berresheim H (2006) Strong correlation between levels of tropospheric hydroxyl radicals and solar ultraviolet radiation. Nature 442:184-187

33. Yang E, Zha J, Jockel J, Boise LH, Thompson CB, Korsmeyer SJ (1995) Bad, a heterodimeric partner for $\mathrm{BCl}-\mathrm{XL}$ and $\mathrm{BCl}-2$, displaces Bax and promotes cell death. Cell 80:285-291
Ready to submit your research? Choose BMC and benefit from:

- fast, convenient online submission

- thorough peer review by experienced researchers in your field

- rapid publication on acceptance

- support for research data, including large and complex data types

- gold Open Access which fosters wider collaboration and increased citations

- maximum visibility for your research: over 100M website views per year

At $\mathrm{BMC}$, research is always in progress.

Learn more biomedcentral.com/submissions 